症例

原発巣と転移巣で異なった組織像を示した AFP 産生胃癌の 1 例

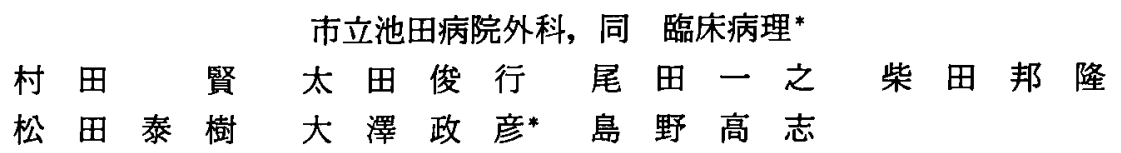

症例は82歳女性. 胃前庭部の胃癌の診断にて幽門側胃切除術を施行した。術前の血清 AFP 值, CA19-9值はそれぞれ1,100ng $/ \mathrm{ml}, 220 \mathrm{U} / \mathrm{ml}$ と高値を示した. 原発巣の病理組 織像は tub2〜 por1で転移リンパ節の病理組織像は por1であった。免疫組織学的に AFP 陽性細胞は原発巣の tub2のごく一部と por1の像を示した転移リンパ節の広範囲に認め られた.CA19-9陽性細胞は原発巣, 転移リンパ節ともに広範囲に認められた。原発巣と 転移巣で異なった組織像を示した AFP 産生胃癌は叒めて稀であり, AFP 産生胃癌の多 彩な分化能を示す示唆に富む症例であると考えられた。

索引用語：AFP, AFP 産生胃癌, リンパ節転移

\section{緒 言}

Alpha-fetoprotein (AFP) 産生胃癌については1970 年 Bourreille らりによってはじめて記載されて以来, 多くの症例報告や臨床病理学的検討がなされている. 肝転移やリンパ節転移をきたしやすく予後不良な疾患 群であると考えられているが，その生物学的特性につ いては不明な点も多く, 補助化学療法に確立されたも のがないのが現状である. 今回, われわれは原発巣と 転移リンパ節で異なる組織像を示した AFP 産生胃癌 の 1 例を経験したので, 文献的考察を加え報告する.

$$
\text { 症例 }
$$

患者：82歳，女性.

主訴：心窝部痛.

家族歴および既往歴：特記すべき事項なし。

現病歴：約 1 年前より心窝部痛があり，平成 8 年12 月13日，当院内科を受診した，胃内視鏡にて胃癌の診 断を受け，同年12月27日，手術目的で当科入院となっ た.

入院時現症：眼瞼結膜に負血を認めた。黄疸は認め なかった. 腹部は平坦軟で, 体表のリンパ節は触知し なかった，直腸診では異常を認めなかった。

入院時検查成績：表 1 に示す. $\mathrm{Hb}$ 值は $8.0 \mathrm{~g} / \mathrm{ml}$ と 實血を認めた。血清アルブミン値は $2.5 \mathrm{~g} / \mathrm{dl}$ と低值を 示した. 血清 AFP 値, 血清 carbohydrate antigen 19.

1998年 3 月27日受付 1998 年 8 月12日採用
9 (CA19-9) 值はそれぞれ1,100ng $/ \mathrm{ml}, 220 \mathrm{U} / \mathrm{ml}$ と高 値を示したが, 血清 carcinoembryonic antigen(CEA) 值は4.0ng/ml と正常範囲内であった。

胃内視鏡所見：胃前庭部小彎後壁に Borrmann II 型の病変を認め, 生検にて中分化型管状腺癌の診断を 得た。

腹部 CT 所見：肝に異常所見は認めなかった．胃小 彎にリンパ節の腫大を認めた。

以上より AFP, CA19-9産生胃癌, リンパ節転移陽性 の診断で手術を施行した。

手術所見: 平成 9 年 1 月 7 日手術を施行した. 開腹 所見は $\mathrm{P}_{0}, \mathrm{H}_{0}, \mathrm{~T}_{2}$ (SS), $\mathrm{N}_{2}$, stage IIIa であった。 幽門側胃切除術を施行し， 2 群のリンパ節郭清を行っ た.

切除標本：胃前庭部に $5 \times 8 \mathrm{~cm}$ の Borrmann II 型胃 癌を認めた（図 1).

切除標本の病理組織像：原発巣の病理組織像は tub2 por1, medullary type, INF $\beta, \mathrm{t} 2$ (ss), ly2, v1であった，胞体は比較的明るく，明らかな好酸性胞 体を有する腫瘍細胞はほとんどなく, 肝様腺癌の組織 像はみられなかった。また yolk sac tumor 様の組織像 もみられなかった７番のリンパ節に 1 個転移を認め た(n2). 転移リンパ節には tub2の像はみられず,すべ て por1の像を呈した(図 2). 総合的進行程度は stage IIIaであった。

原発巣の免疫組織染色像：AFP 染色では tub2の部 
表 1 入院時検査成績

\begin{tabular}{|c|c|c|c|c|}
\hline $\mathrm{RBC}$ & 370 万 $/ \mu 1$ & & T.Prot & $4.7 \mathrm{~g} / \mathrm{dl}$ \\
\hline $\mathrm{Hb}$ & $8.0 \mathrm{~g} / \mathrm{dl}$ & & Alb & $2.5 \mathrm{~g} / \mathrm{ml}$ \\
\hline Het & $28.40 \%$ & & T.Bil & $0.3 \mathrm{mg} / \mathrm{dl}$ \\
\hline WBC & $5,070 / \mu 1$ & & GOT & $13 \mathrm{IU} / l$ \\
\hline Plt & 46.8 万 $/ \mu 1$ & & GPT & $5 \mathrm{IU} / l$ \\
\hline 腫痬マーカー & & & ALP & $238 \mathrm{IU} / l$ \\
\hline AFP & $1.100 \mathrm{ng} / \mathrm{ml}$ & (正常値 $<20 \mathrm{ng} / \mathrm{ml}$ ) & $\gamma \mathrm{GTP}$ & $4 \mathrm{IU} / l$ \\
\hline CA19-9 & $220 \mathrm{U} / \mathrm{ml}$ & (正常値 <37 U/ml) & LDH & $387 \mathrm{IU} / l$ \\
\hline \multirow[t]{4}{*}{ CEA } & $4.0 \mathrm{ng} / \mathrm{ml}$ & (正常値<5 ng/ml) & BUN & $13 \mathrm{mg} / \mathrm{dl}$ \\
\hline & & & $\mathrm{Na}$ & $137 \mathrm{mEq} / \mathrm{l}$ \\
\hline & & & $\mathrm{K}$ & $5.3 \mathrm{mEq} / l$ \\
\hline & & & $\mathrm{Cl}$ & $107 \mathrm{mEq} / l$ \\
\hline
\end{tabular}

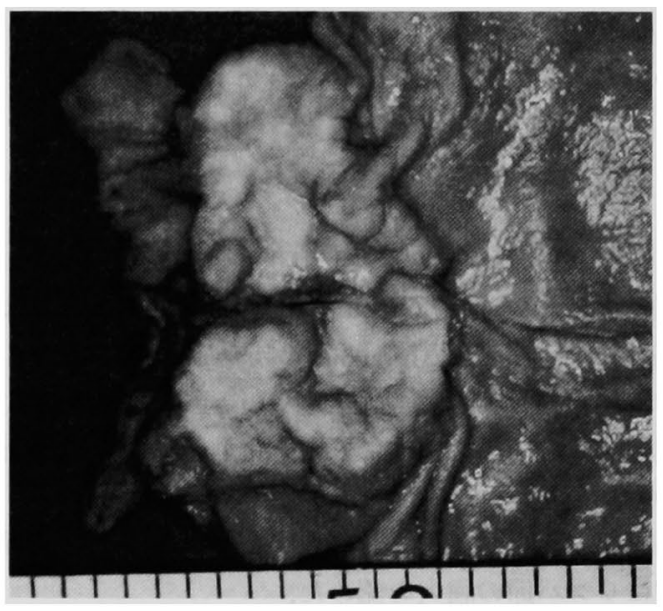

図 1 切除標本 : 胃前庭部に $5 \times 8 \mathrm{~cm}$ の Borrmann II 型胃癌を認めた。

位のごく一部に陽性細胞を認めた，染色の局在様式は Hamada らの分類では, cytoplasmic type であった. CA19-9染色では tub2，por1の部位でともに陽性細胞 を広範囲に認めた。染色の局在様式は cytoplasmic typeであった（図 3).

転移リンパ節の免疫組織染色像：AFP 染色では原 発巣と異なり転移リンパ節の約 $40 \%$ の腫瘍細胞が陽性 であった.CA19-9染色では原発巣と同样, 陽性細胞を 広範囲に認めた。染色の局在様式はともに cytoplasmic typeであった（図 4 ).

術後経過：経過は良好で平成 9 年 1 月24日退院し た. 術後 3 力月で血清 AFP 值, 血清 CA19-9值はそれ ぞれ $5 \mathrm{ng} / \mathrm{ml}$ 以下, $10 \mathrm{U} / \mathrm{ml}$ 以下と正常化した。術後 1 年経過したが, AFP, CA19-9の再上昇はなく, 再発の 兆候は認めていない.

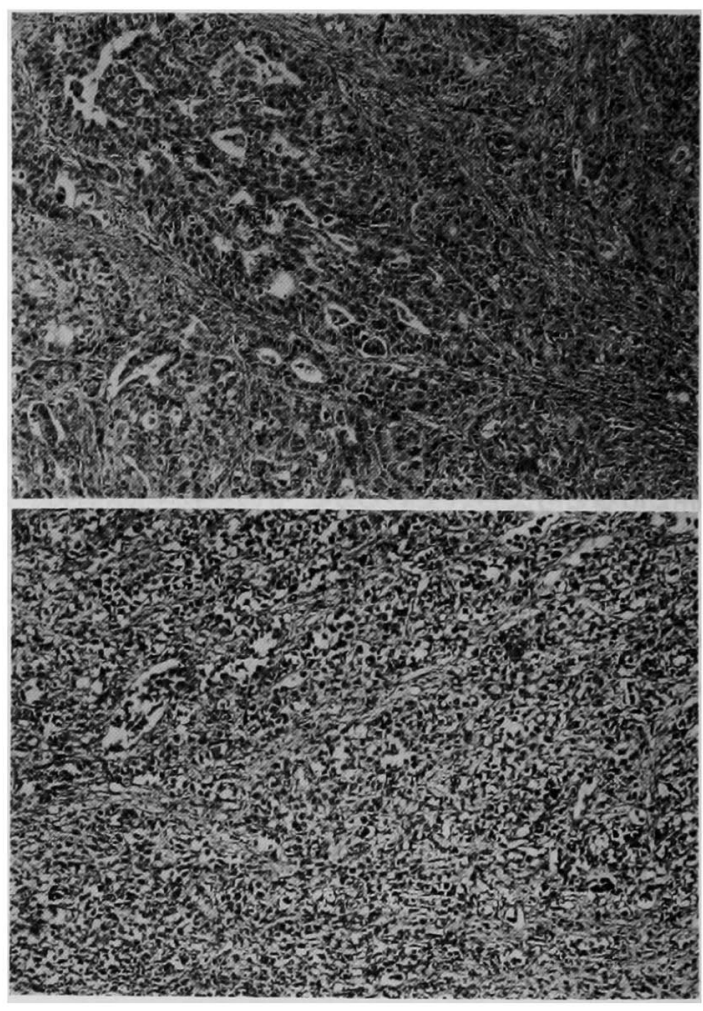

図 2 切除標本の病理組織像 $(\mathrm{HE}, \times 75)$ : 原発巣の 病理組織像は tub2 por1, medullary type, INF $\beta$, t2, ly2, v1であった。肝様腺癌様や yolk sac tumor 様の組織像はみられなかった(上)。転移リンパ節に は tub2の部位はなく por1の像を示した（下）.

\section{考 察}

AFP 産生胃癌は1970年 Bourreilleら”によっては じめて記載されて以来多くの報告や研究がなされてい る.諸家の報告によれば胃癌における血清 AFP の陽 


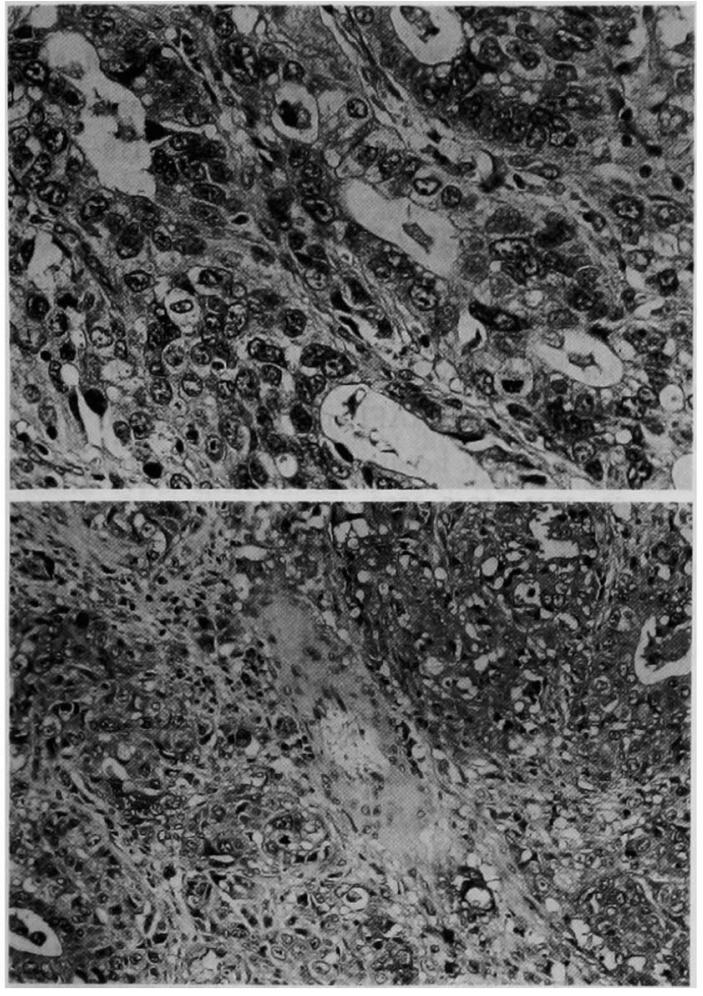

図 3 原発巣の免疫組織染色像：AFP 染色では tub2 の部位のごく一部に陽性細胞を認めた（上, $\times 300)$. CA19-9染色では tub2，por1の部位でともに陽性紐 胞を広範囲に認めた（下, ×150)。

性率は1.2〜6.1\%である ${ }^{3) ~ 5) . ~ I s h i k u r a ~ ら ~}{ }^{6)}$ は AFP 産 生胃癌で形態学的, 免疫組織学的に肝への分化を示す ものに対して肝様腺癌という概念を提唱した。しかし その後, 形態学的に肝様腺癌の像を呈さず, 免疫組織 学的に AFP 染色陽性像を呈し形質変化のみを起こし たと考えられる症例も報告されている7). 一方 Ooi ら は, AFP 産生胃癌のなかに形態上 hepatoid 様の分化 を示さない yolk sac 型の胃癌もあると報告した。AFP 糖鎖に対する concanavalin A の吸着性の差異により hepatoid 型, yolk sac 型の鑑別が可能であるが, 樫村 $ら^{9)}$ は AFP 産生胃癌 7 例中 5 例が yolk sac 型, 2 例 が hepatoid 型であったと報告した。AFP 産生胃癌の 組織像は, 分化型腺癌が多いとするものと低分化型腺 癌が多いとするのと一定していないが，間質に乏しく 髓様増殖が特徽であるとする報告が多い(10)11). AFP 産 生胃癌は一般的に予後は不良で, その主因子は高度の 脈管侵襲に基づく血行性転移やリンパ節転移であると 考えられている. 進行癌が多いが早期癌でも再発例が

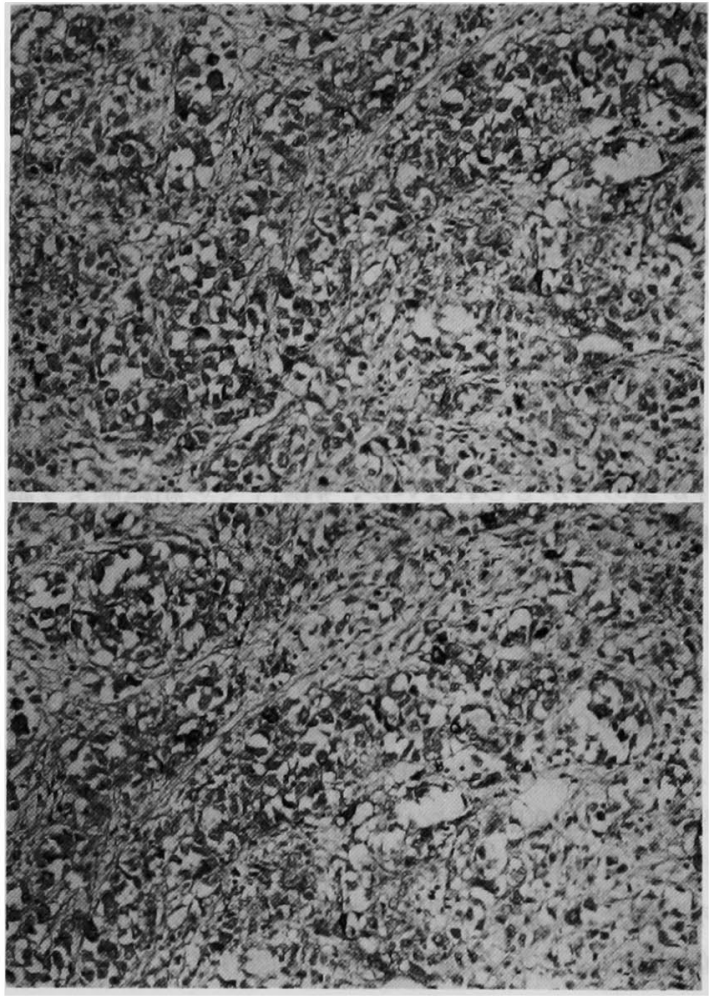

図 4 転移リンパ節の免疫組織染色像：AFP 染色で は転移リンパ節の約 $40 \%$ の細胞が陽性であった (上, × 150)。CA19-9染色では陽性細胞を広範囲に認 めた $($ 下, $\times 150)$.

多く報告されており，腫瘍細胞が静脈，リンパ節，肝 への親和性を有する可能性が考えられるがその詳細な 機序は明らかになっていない10).

本症例の原発巣は tub2 por1の像で tub2の部位の ごく一部にのみ AFP 陽性細胞が観察された。一方転 移リンパ節には tub2の像はなく por1で占められてい たがその約40\%に AFP 陽性細胞がみられた。このこ とは AFP 産生細胞がリンパ節転移をきたしやすいと の報告 ${ }^{(0)}$ と一致するが, さらに原発巣の AFP 陽性で tub2の像を示した癌細胞が転移したリンパ節内て por1に形態変化した可能性と原発巣のAFP陰性て por1の像を示した癌細胞が転移したリンパ節内て AFP 産生細胞に形質変化した可能性が考えられる.

原発巣と転移巣の AFP 産生細胞の組織学的な比較 を行った報告は少ない. 小松ら ${ }^{12)}$ は原発巣に比して転 移リンパ節で AFP 陽性細胞が多い症例を報告した が, 陽性細胞はいずれも肝様腺癌の像を呈し組織型に 差はみられなかった。一方, 名取ら ${ }^{13)}$ は原発巣が中間型 
の低分化型腺癌で転移リンパ節にのみ肝様腺癌と $\mathrm{AFP}$ 陽性細胞を認めた症例を報告し,転移リンパ節で AFP 陽性細胞に形質転換した可能性を示した。これら の報告より AFP 産生細胞の存在様式については一定 の傾向はみられておらず，したがって本症例の AFP 産生細胞の存在様式は極めて興味深く, AFP 産生胃癌 の多彩な分化能を示す示唆に富む症例であると考えら れた。

奥川14)は術後 AFPがすみやかに低下し6力月後正 常の症例は長期生存が望めるとした。本症例も長期生 存が望めるかもしれないが, 病期やその組織像より厳 重な観察が必要であると考えられる。

一方, 胃癌において血清 CA19-9の陽性率は 25〜 67\% と報告されており, 病期や腫瘍細胞増殖能と 相関すると考えられている( ${ }^{15 \sim 17)}$. 広瀬ら ${ }^{181}$ は, 転移り ンパ節の CA19-9染色陽性率は高く, 血清 CA19-9值は リンパ節転移巣の染色陽性例で有意に高值であったこ とより，CA19-9はリンパ行性に胸管経路で末梢血に移 行すると報告した。本症例でCA19-9陽性細胞が多数 みられたことは AFP 産生胃癌の多彩な分化能の 1 側 面であるとともに病期の進行と相関するとの過去の報 告と一致していると考えられる.

$$
\text { 結語 }
$$

原発巣と転移リンパ節で異なる組織像を示した AFP 産生胃癌の 1 例を経験し, 免疫組織学的検討を 行ったので，文献的考察を加え報告した。

\section{女 献}

1) Bourreille J, Metayer $P$, Sauger $F$, et al: Existence d'alpha-fetoprotein au cours d'un cancer secondaire du foie d'origine gastrique. Press Med 78: 1277-1278, 1970

2) Hamada $Y$, Yamamura $M$, Hioki $K$, et al: Immunohistochemical study of carcinoembrionic antigen in patients with colorectal cancer. Cancer 55 : 136-141, 1985

3）山中英司, 中根泰司, 田中完児他：AFP 産生胃癌 17例の検討. 癌の臨 $32: 1934-1940,1986$

4) 高橋 豊, 䵇伊正義, 萩野知已他: AFP 産生胃癌 の臨床病理学的検討一胃癌における AFP の意義 一。外会誌 $88: 696-699,1987$

5）国枝克行, 佐治重豊, 川口順敬他：血清 $\alpha$-fetoprotein 陽性胃癌の臨床病理学的特徵と增殖活性, 基底膜形成に関する検討. 日消外会誌 $30: 2231$
$-2238,1997$

6) Ishikura $H$, Kirimoto $K$, Shamoto $M$, et al: Hepatoid adenocarcinoma of the stomach. An analysis of seven cases. Cancer 58: 119-126, 1986

7) 岩崎 誠, 山際健太郎, 草川雅之他：AFP および CA19-9 産生胃癌の 1 例. 日臨外医会誌 $54: 3056$ $-3060,1993$

8) Ooi A, Nakanishi I, Sakamoto N, et al: Alphafetoprotein (AFP)-producing gastric carcinoma. Is it hepatoid differenciation? Cancer $65: 1741-1747,1990$

9）樫村弘隆, 下田忠和, 池上雅博：AFP 産生胃癌の 形質発現に関する検討. 日消病会誌 92：751一 760,1995

10）太田大作，暒原義史，原田英二他：Alpha-fetoprotein 産生胃癌に関する臨床的, 病理学的検討. 日消外会誌 $18: 43-49,1985$

11）西尾幸男, 襄川公章, 中本光春他： $\alpha$-fetoprotein (AFP) 産生胃癌 9 例の検討. 日臨外医会誌 50 : $1176-1180,1989$

12）小松俊一郎, 早川直和, 加藤政隆他：Alpha-fetoprotein (AFP) 産生胃癌の 1 例一AFP 産生細胞の 局在様式を中心にして一，日臨外医会誌 $52: 583$ -586, 1991

13）名取志保, 若杉純一, 遠藤 格他：転移リンパ節が 肝様腺癌を呈した CA19-9産生胃癌の 1 例. 日消外 会誌 $27: 2583-2586,1994$

14）奥川 保：Alpha-fetoprotein (AFP) 産生胃癌の 臨床病理学的検討と AFP の組織学的型判別につ いて. 横浜医 $46: 607-615,1995$

15）岩井裕子：胃癌患者における 4 種腫瘍マーカー combination assay と免疫組織学的検討の意義に ついて. 日消外会誌 $23: 1821-1829,1990$

16) 古川 信, 小坂 進, 櫛引 健他：新しい消化器癌 関連抗原(CA19.9) の検討一CEA, IAP との対比. 癌の臨 $30: 357-362,1984$

17）荒井泰行, 小林聖明, 尾崎隆彦他：消化器癌におけ る楉鎖抗原 CA19-9 の測定とその臨床意義. 癌と 化療 $11: 917-925,1984$

18）広瀬忠次, 生田目公夫：胃癌における CEA, CA19-90末梢血移行経路に関する検討. 日消外会 誌 $27: 2079-2086,1994$ 


\title{
A CASE OF AFP PRODUCING GASTRIC CANCER WITH DIFFERENT HISTOLOGICAL FEATURE IN THE PRIMARY AND THE METASTATIC LESIONS
}

\author{
Masaru MURATA, Toshiyuki OHTA, Kazuyuki ODA, Kunitaka SHIBATA, \\ Yasuki MATSUDA, Masahiko OHSAWA and Takashi SHIMANO \\ Department of Surgery and Pathology, Ikeda Municipal Hospital
}

An 82-year-old woman was admitted to the hospital because of a gastric cancer in the antrum. Distal gastrectomy was uneventfully performed. Preoperative serum AFP and CA 19-9 levels were as high as $1100 \mathrm{ng} / \mathrm{ml}$ and $220 \mathrm{U} / \mathrm{ml}$, respectively. Histopathologically, the primary lesion was classified as moderately to poorly (solid type) differentiated adenocarcinoma, and the metastatic lymph nodes as poorly (solid type) differentiated adenocarcinoma. Immunohistochemically, AFP positive cancer cells were detected in some parts of tube 2 of the primary lesion, and in major parts of porl of the metastatic lymph nodes. CA19-9 positive cancer cells were detected in both the primary lesion and the metastatic lymph nodes extensively. An AFP producing gastric cancer with different histological feature in the primary and the metastatic lesions is considered to be rare, and this case is highly suggestive in relation to multiple differentiation of AFP producing gastric cancer. 